\title{
MOTIVAÇÃO E SURGIMENTO DO PERFIL EMPREENDEDOR
}

Congresso Nacional Online de Empreendedorismo, 3ạ edição, de 06/12/2021 a 08/12/2021 ISBN dos Anais: 978-65-81152-30-7

SANTOS; André Luis Gregório dos Santos ${ }^{1}$, TEIXEIRA; Natalya da Silva ${ }^{2}$, PETRUCCl; Elvis Da Silva ${ }^{3}$, AZEVEDO; Magno Santana Azevedo ${ }^{4}$, ÁVILA; Wellington 5

\section{RESUMO}

É muito comum de existir profissionais resistentes à ideia de receber ordens ou de ter o seu período de trabalho controlado por outra pessoa, ou pessoas que precisam de recurso financeiro para manter as suas vidas. Em algumas circunstâncias emergentes da vida, surgem ideias inovadoras e o perfil empreendedor de muitos começa a surgir, como por exemplo, o desemprego oriundo da pandemia e o surgimento de diversos novos negócios. O objetivo deste trabalho é avaliar os fatores motivadores do perfil empreendedor em inúmeras pesssoas com perfis e necessidades diferentes diante da atual conjuntura. Foi realizada uma pesquisa de literaturas especializadas em ideias inovadoras e transformadoras de organizações reconhecidas mundialmente, comparando o conhecimento tácito dos autores diante dos conhecimentos explícitos adquiridos durante o desenvolvimento do trabalho. Foi verificado que o perfil empreendedor é aquele que resolve assumir o risco de iniciar um negócio, independente do ramo e das surpresas que irá encontrar ao longo do tempo. A sociedade que se pode chamar de empreendedora é capaz de imaginar, desenvolver e realizar o que imaginou e idealizou como foco, são aquelas pessoas diferenciadas, dotadas de motivação única e apaixonadas pelo que fazem e confiantes no pleno sucesso. O perfil empreendedor é dotado de forte desejo de impressionar com uma marca e a tornar reconhecida, enfrentar junto com ela e um conjunto de ideias as oportunidades de entrada no mercado, buscando torná-la confiável e forte, investigando tudo que for necessário para a criação de seu crescimento e potencializando com informações o plano de negócios, viabilizando o gerenciamento mais assertivo do mpreendimento minimizando alguns riscos e incertezas ao longo de sua construção.

PALAVRAS-CHAVE: Crescimento, Empreendedor, Motivação, Perfil Empreendedor, Riscos 